\title{
Bingchamides $A$ and $B$, two novel cyclic pentapeptides from the Streptomyces bingchenggensis: fermentation, isolation, structure elucidation and biological properties
}

\author{
Wen-Sheng Xiang ${ }^{1}$, Ji-Dong Wang ${ }^{2}$, Xiang-Jing Wang ${ }^{1}$ and Ji Zhang ${ }^{1}$
}

Two novel cyclic pentapeptides, bingchamides A (1) and B (2), have been isolated from the organic extracts of the mycelium of Streptomyces bingchenggensis. The structures of 1 and 2 were elucidated on the basis of extensive 1D and 2D NMR, as well as HRESI-MS, electrospray ionization-MS, UV and IR spectroscopic data analysis. Bingchamides A (1) and B (2) exhibited in vitro cytotoxicity toward human colon carcinoma cell line HCT-116 with the $I_{50}$ values of 14.1 and $18.0 \mu \mathrm{g} \mathrm{ml}^{-1}$, respectively. The bingchamides $A(1)$ and $B(2)$ scaffolds are probably promising structures for the development of new antitumor agents. The Journal of Antibiotics (2009) 62, 501-505; doi:10.1038/ja.2009.60; published online 17 July 2009

Keywords: antitumor activity; bingchamides A and B; cyclic pentapeptides; Streptomyces bingchenggensis

\section{INTRODUCTION}

In the course of screening for new biologically active compounds from microbial sources, an actinomycete strain, Streptomyces bingchenggensis, was isolated from a soil sample collected in Harbin, China. The fermentation broths of $S$. bingchenggensis possess not only potent acaricidal and nematocidal activity, but also antitumor activity. In the previous research, we isolated compounds with potent acaricidal and nematocidal activity, milbemycins $\beta_{13}, \beta_{14}, \alpha_{28}, \alpha_{29}, \alpha_{30}$, secomilbemycins A, B, ${ }^{1-3}$ and a novel macrolide compound, ST906 ${ }^{4}$ with antitumor activity, from S. bingchenggensis. We investigated the fermentation broths of this microorganism in more detail and have isolated two new cyclic pentapeptide compounds, bingchamides A (1) and B (2, Figure 1). The structures of $\mathbf{1}$ and $\mathbf{2}$ were elucidated on the basis of extensive 1D and 2D NMR, as well as HRESI-MS, electrospray ionization (ESI)-MS, UV and IR spectroscopic data analysis. Bingchamides A (1) and B (2) possessed potent cytotoxicity against human cancer cell lines in vitro, and are structurally related to sansalvamide A (3, Figure 1), which is also a potent cytotoxic compound isolated from a marine fungus, Fusarium spp. ${ }^{5}$ We describe in this paper the fermentation, isolation, structure elucidation and biological properties of $\mathbf{1}$ and $\mathbf{2}$. To evaluate their anticancer activities in vitro, we used the drug-resistant human cancer cell line HCT-116. ${ }^{6-10}$

\section{RESULTS AND DISCUSSION}

\section{Structural elucidation}

Compound $\mathbf{1}$ was obtained as a colorless oil with the UV absorptions at $\lambda_{\max }$ of 232 and $275 \mathrm{~nm}$. The molecular formula of 1 was established as $\mathrm{C}_{40} \mathrm{H}_{51} \mathrm{~N}_{5} \mathrm{O}_{5}$ on the basis of HRESI-MS and NMR analysis, which indicated the presence of 18 degrees of unsaturation. The IR absorption at $1651 \mathrm{~cm}^{-1}$ indicated the presence of amide functionalities. In the ${ }^{13} \mathrm{C}$ NMR spectrum of $\mathbf{1}$, five signals were observed between $\delta 169$ and 174, values that are typically assigned to the carbonyls of a peptide. In total, five ${ }^{13} \mathrm{C}$ NMR signals between $\delta 51$ and 63 were characteristic of the $\alpha$-carbons of amino acid residues. The assignment of five amide groups accounted for all of the nitrogen, oxygen and five of the degrees of unsaturation required by the molecular formula. A total of 12 signals in the aromatic region of the ${ }^{13} \mathrm{C}$ NMR spectrum between $\delta 126$ and 138 were characteristic of three mono-substituted phenyl groups, and suggested the presence of three phenylalanine (Phe) residues, which accounted for an additional 12 unsaturations, and left one remaining unsaturation, requiring that 1 possesses one ring. Application of 2D NMR techniques $\left({ }^{1} \mathrm{H}-{ }^{1} \mathrm{H}\right.$ COSY, heteronuclear multiple quantum coherence (HMQC) and heteronuclear multiple bond correlation (HMBC)), which allowed for the identification of all of the amino acid residues of $\mathbf{1}$, revealed the presence of leucine (Leu), isoleucine (Ile), two phenylalanines (Phe-1 and Phe-2) and one $\mathrm{N}-\mathrm{Me}$ phenylalanine (N-Me-Phe). Two- and three-bond HMBC correlations from the $\alpha$ - and/or $\beta$-protons of each residue to their neighboring carbonyl carbons and the NOESY experiments were useful in assigning the carbonyl signals and in establishing the amino acid sequence of $\mathbf{1}$ (Figure 2). The three-bond HMBC correlation from the $\beta$-protons $(\delta 2.80,3.16)$ of N-Me-Phe to the carbonyl carbon at $\delta$ 169.5 assigned the carbonyl carbon belonging to the residue of N-MePhe. The observed HMBC correlation from $\delta_{\mathrm{H}} 1.45$ to $\delta_{\mathrm{C}} 173.4$ and

${ }^{1}$ School of Life Science, Northeast Agricultural University, Harbin, China and ${ }^{2}$ Zhejiang Hisun Pharmaceutical, Taizhou, Zhejiang, China

Correspondence: Professor X-J Wang, School of Life Science, Northeast Agricultural University, Harbin 150030, China.

E-mail: wangxiangjing2008@yahoo.com.cn

Received 11 March 2009; revised 17 June 2009; accepted 25 June 2009; published online 17 July 2009 
<smiles>CCC(C)C1NC(=O)C(CC(C)C)NC(=O)C(Cc2ccccc2)N(C)C(=O)C(Cc2ccccc2)NC(=O)C(Cc2ccccc2)NC1=O</smiles>

1<smiles>CCC(C)C1NC(=O)C(CC(C)C)NC(=O)C(Cc2ccoc2)N(C)C(=O)C(Cc2ccccc2)NC(=O)C(Cc2ccccc2)NC1=O</smiles>

3- (Furan-3-yl)- N-Me- Ala<smiles>COC(C)CC(OC(=O)C(CC(C)C)NC(=O)C(Cc1ccccc1)NC(=O)C(CC(C)C)NC(=O)C(NC(=O)C(CC(C)C)C(C)C)C(C)C)C(=O)O</smiles>

3

Figure 1 The structures of bingchamides A (1), B (2) and sansalvamide A (3).

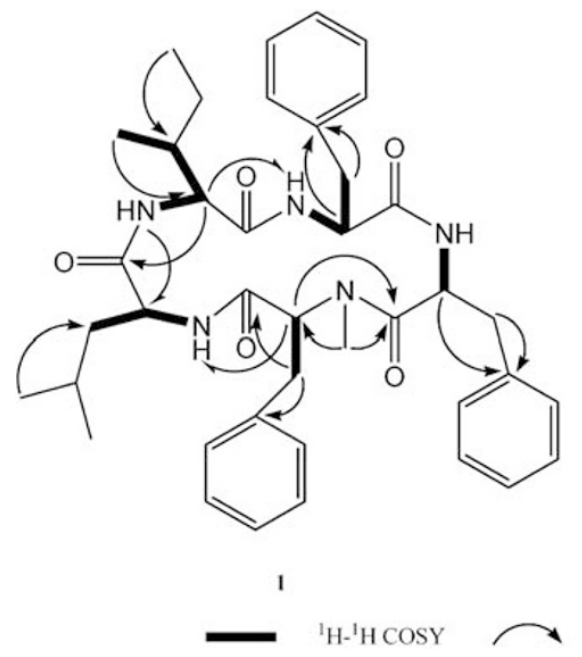

Figure 2 The key ${ }^{1} \mathrm{H}-{ }^{1} \mathrm{H}$ COSY, HMBC and NOESY correlations of $\mathbf{1}$ and $\mathbf{2}$.

from $\delta_{\mathrm{H}} 2.93$ to $\delta_{\mathrm{C}} 171.8$ assigned the carbonyl carbons belonging to the residue of Leu and Phe-1, respectively. The remaining two overlapped carbon signals at $\delta 170.7$ were the carbonyl carbons of the residues of Phe-2 and Ile. In its HMBC spectrum, correlation of the proton signal of $\mathrm{N}-\mathrm{Me}(\delta 2.69)$ and the amide carbonyl carbon at $\delta$ 171.8 established the partial sequence Phe- $\rightarrow \mathrm{N}-\mathrm{Me}-\mathrm{Phe}$. The longrange ${ }^{1} \mathrm{H}-{ }^{13} \mathrm{C}$ correlation between $\delta_{\mathrm{H}} 3.33$ and $\delta_{\mathrm{C}} 173.4$ and 170.7 established the partial sequence Leu $\rightarrow$ Ile. By the ${ }^{1} \mathrm{H}-{ }^{1} \mathrm{H}$ COSY spectrum, four $\mathrm{NH}$ proton signals were assigned to their respective amino acid residues (Table 1). The key NOESY signal between $\delta 5.21$ and $\delta 6.77$ connected the N-Me-Phe to Leu. The sequence of four amino acid residues (Phe-1, N-Me-Phe, Leu and Ile) was completed. Consequently, the remaining Phe- 2 connected with Ile and Phe-1, and was acylated by Ile. Thus, the overall sequence for 1 was established in the only way possible.

The stereochemistry of $\mathbf{1}$ remained unknown because of the absence of correlation signals of the five $\alpha$-protons of the five amino acid residues in the NOESY experiment and the poor amount of $\mathbf{1}$. To confirm the structure of $\mathbf{1}$ and establish its conformation, chemical synthesis of $\mathbf{1}$ is ongoing.

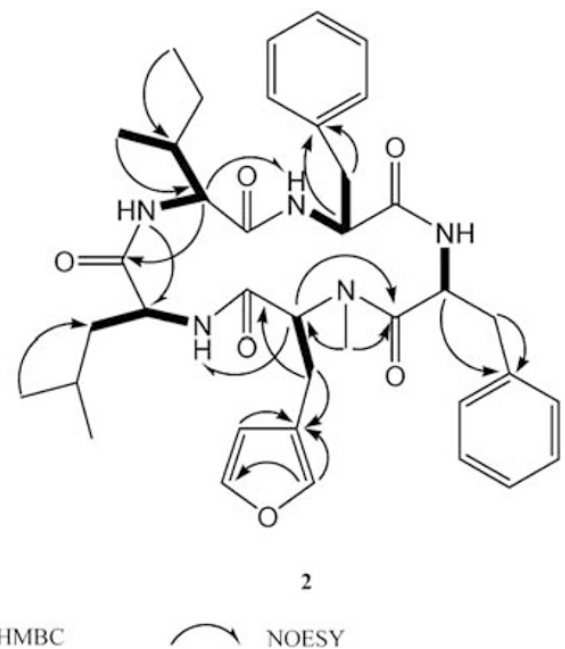

Compound 2 was also obtained as a colorless oil. The molecular formula of 2 was deduced from HRESI-MS $m / z 694.3593\left((\mathrm{M}+\mathrm{Na})^{+}\right.$, calcd for $\left.\mathrm{C}_{38} \mathrm{H}_{49} \mathrm{~N}_{5} \mathrm{O}_{6} \mathrm{Na}, 694.3581\right)$ in conjunction with ${ }^{13} \mathrm{C} \mathrm{NMR}$ spectral data. Its ${ }^{13} \mathrm{C}$ NMR data displayed five characteristic $\alpha$-carbon signals of amino acid residues between $\delta 51$ and 63, and the five carbonyl signals between $\delta 169$ and 174 were assigned to the amide carbonyl carbons of a pentapeptide. Detailed comparison of the ${ }^{1} \mathrm{H}$ and ${ }^{13} \mathrm{C}$ NMR data of 2 with those of 1 revealed that four of five amino acid residues of $\mathbf{2}$ were identical to those of $\mathbf{1}$ (Phe-1, Phe-2, Leu and Ile). By further analysis of the HMBC and NOESY correlations (Figure 2), the sequence of the four amino acid residues in $\mathbf{2}$ was the same as shown in 1 . Comparison of the ${ }^{1} \mathrm{H}$ and ${ }^{13} \mathrm{C}$ NMR data of the remaining amino acid residue in $\mathbf{2}$ with those of $\mathrm{N}$-Me-Phe in $\mathbf{1}$ revealed that the difference between them was only in the aromatic moiety. The four carbon signals at $\delta 142.9,139.6,119.5$ and 110.4, and an unassigned oxygen atom in conjunction with the HMBC correlations from $\delta_{\mathrm{H}} 6.04$ to $\delta_{\mathrm{C}} 119.5,139.6,142.9$, from $\delta_{\mathrm{H}} 6.97$ to $\delta_{\mathrm{C}} 119.5$, $110.4,142.9$, from $\delta_{\mathrm{H}} 7.22$ to $\delta_{\mathrm{C}} 119.5,110.4,139.6$ established the presence of a furan ring. The long-range ${ }^{1} \mathrm{H}-{ }^{13} \mathrm{C}$ correlations observed between $\delta_{\mathrm{H}} 2.67,2.87$ and $\delta_{\mathrm{C}} 119.5,139.6$ established the remaining 
Table 1 NMR spectral data for 1 and 2 in $\mathrm{CDCl}_{3}$

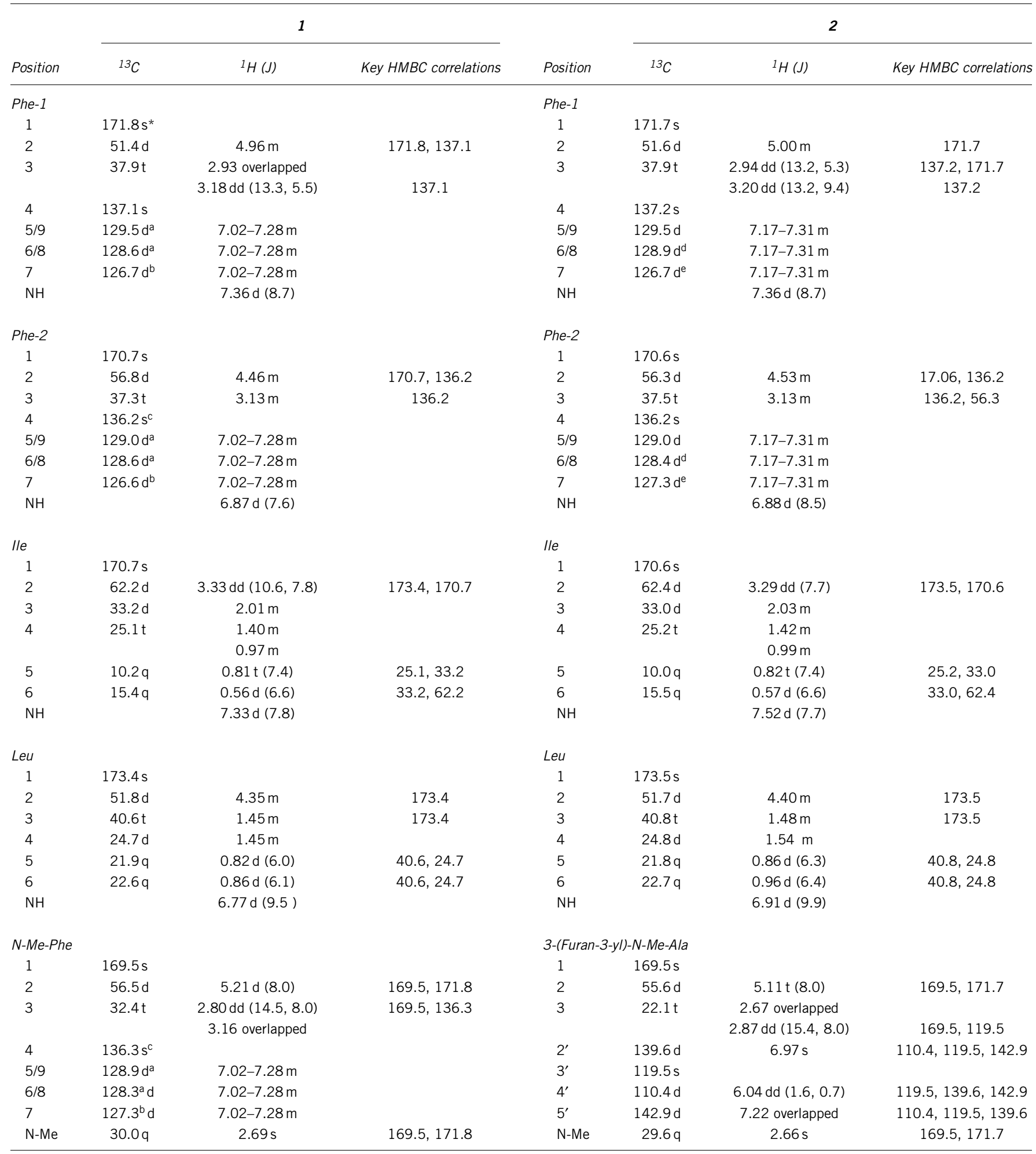

*By DEPT sequence.

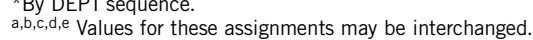

amino acid residue as 3-(furan-3-yl)-N-Me-alanine (3-(furan-3-yl)$\mathrm{N}-\mathrm{Me}-\mathrm{Ala})$. Consequently, the gross structure of $\mathbf{2}$ was elucidated as the similar sequence of 1 except that the residue of 3-(furan-3-yl)-
$\mathrm{N}-\mathrm{Me}-\mathrm{Ala}$ in 2 replaced the residue of $\mathrm{N}-\mathrm{Me}-\mathrm{Phe}$ in $\mathbf{1}$. A furan ring incorporated into a cyclic peptide structure as a natural product is rare. ${ }^{11,12}$ 


\section{Biological activity}

We examined the inhibitory activity of bingchamides A (1) and B (2) against the growth of human colon carcinoma cell line HCT-116 using the CCK- 8 colorimetric method as described in Methods. Compound $\mathbf{1}$ and $\mathbf{2}$ dose-dependently inhibited the growth of HCT-116 cells with IC50 value of 14.1 and $18.0 \mu \mathrm{g} \mathrm{ml}^{-1}$, respectively.

Natural products are excellent sources of potential new drug leads. These novel structures are important for the development of original therapeutic leads that target new biological pathways. ${ }^{13}$ Sansalvamide A is one such natural product (3, Figure 1). A number of analogs have been made. These sansalvamide A derivatives ${ }^{6-10,14-20}$ have shown that they are privileged structures and exhibit potency against multiple targets in numerous cancer cell lines. The examples of potent cytotoxicity against pancreatic, colon, breast, prostate and melanoma cancers clearly indicate the potential of this compound class as a platform useful in targeting these cancers. The structures of bingchamides A (1) and B (2) are similar to sansalvamide A, and they all belong to cyclic pentapeptides. However, there are significant differences among them. This shows that like sansalvamide A, bingchamides A (1) and B (2) scaffolds are probably promising structures for the development of new antitumor agents.

\section{METHODS}

\section{General}

UV spectra were obtained on a Varian CARY 300 BIO spectrophotometer (Varian, Palo Alto, CA, USA); IR spectra were recorded on a Nicolet Magna FT-IR 750 spectrometer (Nicolet, Madison, WI, USA) $\left(v_{\max }\right.$ in $\left.\mathrm{cm}^{-1}\right)$; and ${ }^{1} \mathrm{H}$ and ${ }^{13} \mathrm{C}$ NMR spectra were measured with a Bruker DRX-400 $\left(400 \mathrm{MHz}\right.$ for ${ }^{1} \mathrm{H}$ and $100 \mathrm{MHz}$ for ${ }^{13} \mathrm{C}$ ) spectrometer (Bruker, Billerica, MA, USA). Chemical shifts are reported in parts per million $(\delta)$, using the residual $\mathrm{CHCl}_{3}\left(\delta_{\mathrm{H}} 7.26\right.$ p.p.m.; $\left.\delta_{\mathrm{C}} 77.0\right)$ as an internal standard, coupling constant $(J)$ in $\mathrm{Hz} .{ }^{1} \mathrm{H}$ and ${ }^{13} \mathrm{C}$ NMR assignments were supported by ${ }^{1} \mathrm{H}-{ }^{1} \mathrm{H}$ COSY, HMQC and $\mathrm{HMBC}$ experiments. The ESI-MS and HRESI-MS spectra were taken on a Q-TOF Micromass LC-MS-MS (Waters Corporation, Milford, MA, USA) mass spectrometer. Optical rotation was measured on a Perkin-Elmer 341 Polarimeter (Perkin-Elmer, Fremont, CA, USA). Reversed phase-HPLC was conducted on an Agilent 1100 series (Agilent, Santa Clara, CA, USA). Commercial silica gel (Qing Dao Hai Yang Chemical Group, Qing Dao, China, 100-200 and 200-300 mesh) was used for column chromatography. Spots were detected on TLC under UV or by heating after spraying with sulfuric acid-ethanol, 5:95 (v/v).

\section{Microorganism}

The producing organism, S. bingchenggensis, was isolated from a soil sample collected in Harbin, China. S. bingchenggensis has been deposited at the China General Microbiology Culture Collection Center (Accession no: CGMCC1734), Institute of Microbiology, Chinese Academy of Sciences, and we have determined the 16S rDNA sequence (Accession no: DQ449953 in GenBank, National Center for Biological Information).

\section{Fermentation}

The seed for preculture was spores. The medium for sporulation contained sucrose (Bei Jing Ao Bo Xing, Beijing, China) 4 g, yeast extract (Bei Jing Ao Bo Xing) $2 \mathrm{~g}$, malt extract (Bei Jing Ao Bo Xing) $5 \mathrm{~g}$ and skim milk (Nmyili, Huhehaote, China) $1 \mathrm{~g}$ in 11 water. The $\mathrm{pH}$ was adjusted to 7.0 with $1 \mathrm{~m} \mathrm{NaOH}$, $20 \mathrm{~g}$ of agar was added and this mixture was sterilized at $121^{\circ} \mathrm{C}$ for $30 \mathrm{~min}$. The spore suspension was prepared from the agarplates $(20 \mathrm{ml})$ incubated at $28{ }^{\circ} \mathrm{C}$ for 7-8 days.

A spore suspension of the culture of strain $S$. bingchenggensis, $1 \mathrm{ml}$, was transferred to a 250-ml Erlenmeyer flask that contained $25 \mathrm{ml}$ of the seed medium containing sucrose $0.25 \mathrm{~g}$, polypepton (Bei Jing Ao Bo Xing) $0.1 \mathrm{~g}$ and $\mathrm{K}_{2} \mathrm{HPO}_{4} 1.25 \mathrm{mg}$. The inoculated flasks were incubated at $28^{\circ} \mathrm{C}$ for $42 \mathrm{~h}$ on a rotary shaker at 250 r.p.m. Then $8.0 \mathrm{ml}$ of the culture was transferred into 1-1 Erlenmeyer flask containing $100 \mathrm{ml}$ of the producing medium consisting of sucrose (Bei Jing Ao Bo Xing) 8.0\%, soybean powder (Comwin, Beijing, China) $1.0 \%$, yeast extract (Bei Jing Bo Xing) $0.2 \%$, meat extract (Bei Jing Ao Bo Xing) $0.1 \%, \mathrm{CaCO}_{3}$ (Bei Jing Hong Xin, Beijing, China) $0.3 \%, \mathrm{~K}_{2} \mathrm{HPO}_{4} 0.03 \%$, $\mathrm{MgSO}_{4} \cdot 7 \mathrm{H}_{2} \mathrm{O} 0.1 \%$ and $\mathrm{FeSO}_{4} \cdot 7 \mathrm{H}_{2} \mathrm{O} 0.005 \%$, pH 7.2 before sterilization. Fermentation was carried out at $28^{\circ} \mathrm{C}$ for 8 days in a rotary shaker at 250 r.p.m.

\section{Isolation and purification}

The fermentation broth $(30 \mathrm{l})$ was filtered. The resulting cake was washed with water, and both filtrate and wash were discarded. Methanol (5l) was used to extract the washed cake. The $\mathrm{MeOH}$ extract was concentrated to approximately 11 under reduced pressure and the resulting concentrate was extracted three times with an equal volume of EtOAc. The combined EtOAc phase was concentrated under reduced pressure to yield $50 \mathrm{~g}$ of oily substances. The residual oily substance was chromatographed on silica gel and eluted with petroleum ether-acetone (95:5-50:50) to give five fractions. The semi-preparative HPLC (Agilent 1100, Zorbax SB-C18, $5 \mu \mathrm{m}, 250 \times 9.4 \mathrm{~mm}$ i.d.) was further applied to obtain pure compounds. The eluates were monitored with a photodiode array detector at $220 \mathrm{~nm}$ and the flow rate was $1.5 \mathrm{ml} \mathrm{min}^{-1}$ at room temperature. The fifth fraction (petroleum ether-acetone 1:1) with anticancer activity was separated by semi-preparative HPLC using a solvent of $85 \% \mathrm{CH}_{3} \mathrm{CN} / \mathrm{H}_{2} \mathrm{O}$ to afford $\mathbf{1}$ (11.1 min, $13.0 \mathrm{mg}$ ) and $2(9.8 \mathrm{~min}, 9.5 \mathrm{mg}$ ).

Physico-chemical properties of compounds 1. Bingchamide A (1) $\mathrm{C}_{40} \mathrm{H}_{51} \mathrm{~N}_{5} \mathrm{O}_{5}$, colorless oil; $[\alpha]^{25}{ }_{\mathrm{D}}+103.6^{\circ}$ (c $\left.0.03, \mathrm{EtOH}\right) ; \mathrm{UV}\left(\mathrm{CHCl}_{3}\right) \lambda_{\max } \mathrm{nm}(\log \varepsilon): 232$ (4.8), 275 (3.6); IR (KBr), $v_{\max } \mathrm{cm}^{-1}$ : 3479, 2922, 1651, 1522, 1456, 1124, 699; ${ }^{1} \mathrm{H}$ NMR $\left(\mathrm{CDCl}_{3}, 400 \mathrm{MHz}\right)$ and ${ }^{13} \mathrm{C} \mathrm{NMR}\left(\mathrm{CDCl}_{3}, 100 \mathrm{MHz}\right)$ see Table 1; ESI-MS $m / z 682[\mathrm{M}+\mathrm{H}]^{+}$; HRESI-MS $\mathrm{m} / \mathrm{z} 704.3807\left([\mathrm{M}+\mathrm{Na}]^{+}\right.$, calcd for $\left.\mathrm{C}_{40} \mathrm{H}_{51} \mathrm{~N}_{5} \mathrm{O}_{5} \mathrm{Na}, 704.3788\right)$.

Physico-chemical properties of compounds 2. Bingchamide B (2) $\mathrm{C}_{38} \mathrm{H}_{49} \mathrm{~N}_{5} \mathrm{O}_{6}$,

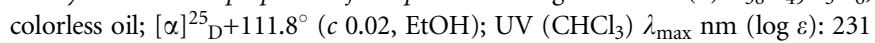
(4.8), 276 (3.7); IR (KBr), $v_{\max } \mathrm{cm}^{-1}$ : 3276, 2928, 1663, 1528, 1458, 1026, 874, 701; ${ }^{1} \mathrm{H}$ NMR $\left(\mathrm{CDCl}_{3}, 400 \mathrm{MHz}\right)$ and ${ }^{13} \mathrm{C} \mathrm{NMR}\left(\mathrm{CDCl}_{3}, 100 \mathrm{MHz}\right)$ see Table 1 ; ESI-MS $m / z 672[\mathrm{M}+\mathrm{H}]^{+}$; HRESI-MS $\mathrm{m} / \mathrm{z} 694.3593\left([\mathrm{M}+\mathrm{Na}]^{+}\right.$, calcd for $\mathrm{C}_{38} \mathrm{H}_{49} \mathrm{~N}_{5} \mathrm{O}_{6} \mathrm{Na}, 694.3581$ ).

\section{Biological assays}

The cytotoxicity of compound on tumor cells was assayed according to the published procedures. ${ }^{21}$ Human colon carcinoma cell line HCT-116 was routinely cultured in Dulbecco's Modified Eagle Media containing $10 \%$ calf serum at $37{ }^{\circ} \mathrm{C}$ for $4 \mathrm{~h}$ in a humidified atmosphere of $5 \% \mathrm{CO}_{2}$ incubator. The adherent cells at their logarithmic growth stage were digested, and were inoculated onto 96 -well culture plate at a density of $1.0 \times 10^{4}$ per well for the determination of proliferation. Test samples were added to the medium, and incubation was continued for $72 \mathrm{~h}$. Coloration substrate, cell-counting kit-8 (CCK-8, Dojindo, Kumamoto, Japan), was added to the medium followed by further incubation for $3 \mathrm{~h}$. Absorbance at $450 \mathrm{~nm}$ with a $600 \mathrm{~nm}$ reference was measured thereafter. Media and DMSO control wells, in which compound was absent, were included in all the experiments to eliminate the influence of DMSO. The inhibitory rate of cell proliferation was calculated by the following formula:

$$
\text { Growth inhibition }(\%)=\left[\mathrm{OD}_{\text {control }}-\mathrm{OD}_{\text {treated }}\right] / \mathrm{OD}_{\text {control }} \times 100
$$

The cytotoxicity of compound on tumor cells was expressed as $\mathrm{IC}_{50}$ values (the drug concentration reducing by $50 \%$ the absorbance in treated cells, with respect to untreated cells) and was calculated by LOGIT method.

\section{ACKNOWLEDGEMENTS}

This study was supported by the National Natural Science Foundation of China (Grant nos. 30571234 and 30771427), the National Key Technology R\&D Program (Grant no. 2006BAD31B) and the Program for New Century Excellent Talents in University.

1 Xiang, W. S., Wang, J. D., Wang, X. J. \& Zhang, J. Two new-class milbemycins from Streptomyces bingchenggensis Fermentation, isolation, structure elucidation and biological properties. J. Antibiot. 60, 351-356 (2007). 
2 Xiang, W. S., Wang, J. D., Wang, X. J., Zhang, J. \& Wang, Z. Further new milbemycin antibiotics from Streptomyces bingchenggensis. J. Antibiot. 60, 608-613 (2007).

3 Xiang, W. S., Wang, J. D., Fan, H. M., Wang, X. J. \& Zhang, J. New Seco-milbemycins from Streptomyces bingchenggensis: fermentation, isolation and structure elucidation. J. Antibiot. 60, 27-32 (2008).

4 Xiang, W. S., Wang, J. D., Wang, X. J. \& Zhang, J. A novel macrolide compound from Streptomyces bingchenggensis fermentation, isolation, structure elucidation and biological properties. J. Antibiot. 62, 229-231 (2009).

5 Hwang, Y. et al. Mechanism of inhibition of a poxvirus topoisomerase by the marine natural product sansalvamide. A. Mol. Pharmacol. 6, 1049-1053 (1999).

6 Lee, Y. \& Silverman, R. B. Rapid, high-yield, solid-phase synthesis of the antitumor antibiotic sansalvamide $A$ using a side-chain-tethered phenylalanine building block. Org. Lett. 2, 3743-3746 (2000).

7 Gu, W., Liu, S. \& Silverman, R. B. Solid-phase, Pd-catalyzed siliconaryl carbon bond formation. Synthesis of sansalvamide A peptide. Org. Lett. 4, 4171-4174 (2002).

8 Carroll, C. L. et al. Synthesis and cytotoxicity of novel sansalvamide A derivatives. Org. Lett. 7, 3481-3484 (2005).

9 Otrubova, K. et al. Synthesis and novel structure-activity relationships of potent sansalvamide A derivatives. Chem. Commun. 9, 1033-1034 (2006).

10 Otrubova, K., McGuire, K. L. \& McAlpine, S. R. Scaffold targeting drug-resistant colon cancers. J. Med. Chem. 9, 1999-2002 (2007).

11 Tan, N. H. \& Zhou, J. Plant Cyclopeptides. Chem. Rev. 106, 840-895 (2006).

12 Liu, Y. Q. et al. Design and synthesis of cyclo[-Arg-Gly-Asp- $\psi$ (triazole)-Gly-Xaa-] peptide analogues by click chemistry. Tetrahedron 47, 10728-10734 (2008).
13 Harvey, A. L. Natural products in drug discovery. Drug Discov. Today 13, 895-901 (2008).

14 Otrubova, K., Lushington, G., McGuire, K. L. \& McAlpine, S. R. Comprehensive study of sansalvamide $A$ derivatives and their structure-activity relationships against drug-resistant colon cancer cell lines. J. Med. Chem. 3, 530-544 (2008).

15 Davis, M. R. et al. Synthesis and cytotoxicity of a new class of potent decapeptide macrocycles. Org. Lett. 2, 177-180 (2008).

16 Pan, P. S., McGuire, K. L. \& McAlpine, S. R. Identification of Sansalvamide A analog potent against pancreatic cancer cell lines. Bioorg. Med. Chem. Lett. 18, 5072-5077 (2007).

17 Rodriguez, R. A. et al. Synthesis of second-generation sansalvamide A derivatives: novel templates as potential antitumor agents. J. Org. Chem. 6, 1980-2002 (2007).

18 Styers, T. J. et al. Synthesis of Sansalvamide A derivatives and their cytotoxicity in the MSS colon cancer cell line HT-2. Bioorg. Med. Chem. 16, 5625-5631 (2006).

19 Otrubova, K. et al. Synthesis and novel structure-activity relationships of potent sansalvamide A derivatives. Chem. Commun. 9, 1033-1034 (2006).

$20 \mathrm{Ujiki}, \mathrm{M}$. B. et al. A novel peptide sansalvamide analogue inhibits pancreatic cancer cell growth through GO/G1 cell-cycle arrest. Biochem. Biophys. Res. Commun. 4, 1224-1228 (2006).

21 Wijnhoven, B. P. et al. Human oesophageal adenocarcinoma cell lines JROECL 47 and JROECL 50 are admixtures of the human colon carcinoma cell line HCT 11 . Br. J. Cancer. 9, 1510-1512 (2000). 